\title{
Acidification and warming affect both a calcifying predator and prey, but not their interaction
}

\author{
Anja Landes ${ }^{1,3}$, Martin Zimmer ${ }^{1,2,4, *}$ \\ ${ }^{1}$ Zoologisches Institut, Christian-Albrechts-Universität zu Kiel, 24118 Kiel, Germany \\ ${ }^{2}$ FB3: Benthic Ecology, IFM-GEOMAR, Leibniz-Institut für Meereswissenschaften, 24105 Kiel, Germany \\ ${ }^{3}$ Present address: DTU Aqua, Sektion for Kystøkologi, Jægersborg Allé 1, 2920 Charlottenlund, Denmark \\ ${ }^{4}$ Present address: FB Organismische Biologie, AG Ökologie, Biodiversität \& Evolution der Tiere, \\ Paris-Lodron-Universität Salzburg, Hellbrunner Str. 34, 5020 Salzburg, Austria
}

\begin{abstract}
Both ocean warming and acidification have been demonstrated to affect the growth, performance and reproductive success of calcifying invertebrates. However, relatively little is known regarding how such environmental change may affect interspecific interactions. We separately treated green crabs Carcinus maenas and periwinkles Littorina littorea under conditions that mimicked either ambient conditions (control) or warming and acidification, both separately and in combination, for $5 \mathrm{mo}$. After $5 \mathrm{mo}$, the predators, prey and predator-prey interactions were screened for changes in response to environmental change. Acidification negatively affected the closermuscle length of the crusher chela and correspondingly the claw-strength increment in C. maenas. The effects of warming and/or acidification on L. littorea were less consistent but indicated weaker shells in response to acidification. On the community level, however, we found no evidence that predator-prey interactions will change in the future. Further experiments exploring the impacts of warming and acidification on key ecological interactions are needed instead of basing predictions of ecosystem change solely on species-specific responses to environmental change.
\end{abstract}

KEY WORDS: Acidification · Warming · Environmental change · Calcification · Predator-prey interaction · Coastal benthic communities

\section{Resale or republication not permitted without} written consent of the publisher

\section{INTRODUCTION}

The periwinkle Littorina littorea (Mollusca: Gastropoda) generally plays a key role in controlling composition and density of the shallow-water algal com-

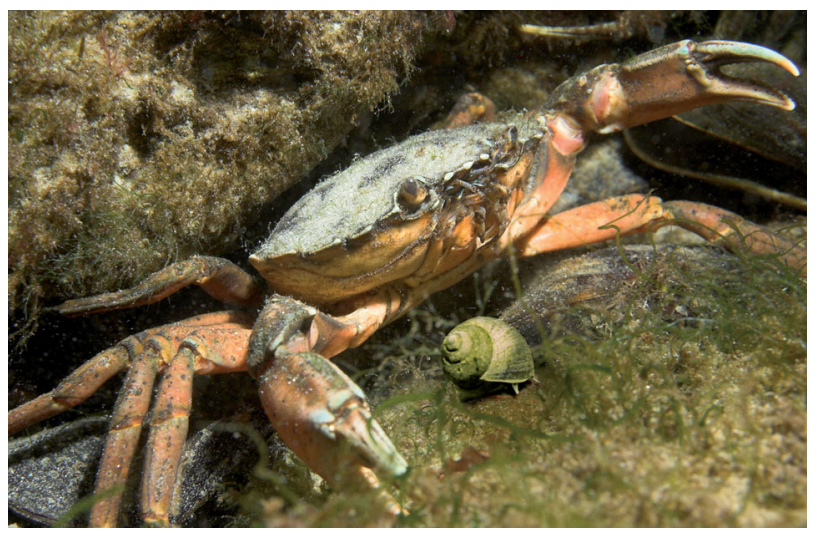

Green crabs Carcinus maenas prey upon hard-shelled herbivores such as periwinkles Littorina littorea, which may control benthic primary production in shallow waters.

Photo: U. Kunz

munity (e.g. Lubchenco 1983, Sommer 2001, Trussell et al. 2002), as is the case in the south-western Baltic Sea. Through consumer preference for ephemeral algae, such as Ulva lactuca and Porphyra spp., slowgrowing perennial fucoid species can develop dense stands where the substratum allows for settlement. Hence, the species composition of the algal community varies with the composition and density of the herbivore community (Lubchenco 1983), which, in turn, are top-down controlled by predators, such as the green crab Carcinus maenas (Crustacea: Decapoda). By this process, predation pressure suppresses snail foraging and results in a trophic cas- 
cade that exerts strong impact on Fucus stands (Trussell et al. 2002), and changes in predator-prey interactions can be predicted to translate into changes in community structure and functioning.

Recently, the sea surface water temperature increased by $0.08^{\circ} \mathrm{C}$ on average per decade in the Baltic Sea, compared to a worldwide warming of $0.05^{\circ} \mathrm{C}$ per decade, resulting in a temperature rise of ca. $0.7^{\circ} \mathrm{C}$ in the last hundred years (HELCOM 2007). By the end of this century, air and surface water temperatures are predicted to increase by a further 3 to $5^{\circ} \mathrm{C}$ in the south-western part of the Baltic, particularly during summer (Siegel et al. 2006). On a global scale, ocean surface water is predicted to warm by 1 to $3^{\circ} \mathrm{C}$ on average, particularly during winter (IPCC 2007).

Although the ocean is capable of taking up $\mathrm{CO}_{2}$ and buffering atmospheric warming to a certain extent, $\mathrm{CO}_{2}$ reacts with seawater to form carbonic acid and its dissociation products, bicarbonate and carbonate ions, accompanied by the release of protons and increased seawater acidity. Owing to rising atmospheric $\mathrm{CO}_{2}$ concentrations, the average sea surface $\mathrm{pH}$-value has already decreased globally by ca. 0.1 units since the beginning of the 20th century (The Royal Society 2005, Caldeira \& Wickett 2003). With respect to progressively increasing $\mathrm{CO}_{2}$ emissions, a further drop in surface water $\mathrm{pH}$ by up to 0.38 units is predicted by 2100 (SMHI 2008).

It is, however, the rate of change rather than the magnitude of change that seems unprecedented in earth's history (cf. IPCC 2007, Tripati et al. 2009), and which has alerted ecologists concerned with global change ecology. It remains unknown whether and to what extent organisms or species will be able to acclimate or adapt to such sudden environmental changes in the long term.

In the short term, changes in temperature or $\mathrm{pH}$ potentially affect the development and growth of marine organisms. In particular, the calcification mechanisms of calcifying marine animals depend on the pH-mediated solubility and saturation rates of aragonite and calcite in seawater (e.g. Ohde \& Hossain 2004). $\mathrm{CO}_{2}$-induced acidification goes handin-hand with reduced carbonate availability in the seawater, hence limiting the growth and performance of calcifying organisms. Yet, although marine snails have been shown to be negatively affected by $\mathrm{CO}_{2}$-induced seawater acidification (Bibby et al. 2007, Hall-Spencer et al. 2008, Ellis et al. 2009), crabs appear to be capable of physiologically counteracting decreasing $\mathrm{pH}$ values in the environment (Pane \& Barry 2007, Spicer et al. 2007, Fehsenfeld et al. 2011). However, $\mathrm{CO}_{2}$ and/or $\mathrm{pH}$ stress reduces the ability to withstand seawater warming (Metzger et al. 2007, Walther et al. 2009) and compromises the crabs' immune response (Tanner et al. 2006). Most of these studies observed crabs only during short-term experiments over hours or few days (but see Small et al. 2010, Fehsenfeld et al. 2011). Hence, it remains essentially unknown how long-term exposure to acidified seawater affects crab performance.

We hypothesize that both warming and acidification will affect the long-term individual performance of both snails and crabs. However, with respect to the predator-prey interactions of calcifying animals, several scenarios are possible: (1) Both predators (Carcinus maenas) and prey (Littorina littorea) are affected similarly. Thus, weakened crab claws will face weakened snail shells, so that the predatory interactions and population dynamics of predators and prey will remain essentially unchanged. (2) Snails will be more susceptible to acidification. Thus, weakened snail shells will be easier to crush by unaffected crabs, resulting in a shift of preferred prey size towards larger snails. This shift will eventually lead to reduced population sizes of snails, provided that larger individuals produce higher numbers of offspring, as has been shown for several Littorina species, such as L. rudis (Roberts \& Hughes 1980), L. saxatilis (Ross \& Berry 1991) and L. neglecta (Johnson 1999). (3) Crab claw strength will be affected more strongly by seawater acidification than snail shell stability. Thus, crabs will shift to preying upon smaller snails, resulting in increased population growth of snails. We tested these scenarios in an experimental long-term treatment (5 mo) of both crabs and snails and with subsequent measurements of predator-prey interactions.

\section{MATERIALS AND METHODS}

\section{Experimental setup}

Different temperatures and $\mathrm{pH}$ values were separately adjusted in 4 closed flow-through seawater cycle systems (capacity of 1501 each), each comprising 10 individual aquaria of $51\left(25 \times 15.5 \times 14.5 \mathrm{~cm}^{3}\right)$ that harbored one crab each. From there, water overflowed (flow rate $52 \pm 10 \mathrm{l} \mathrm{h}^{-1}$ ) into a water-collecting tank (ca. $50 \mathrm{l} ; 55 \times 40 \times 35 \mathrm{~cm}^{3}$ ) underneath and was pumped into a water-providing head tank (ca. $50 l_{\text {; }}$ $55 \times 40 \times 35 \mathrm{~cm}^{3}$ ).

The photoperiod inside the climate chamber was adjusted to the actual seasonal progression during the experimental run of 5 mo from mid-October 2008 to mid-March 2009. Similarly, the temperature was 
adjusted to either actual values measured weekly in the Kiel Fjord (2 systems, 'control-treatment') or elevated above ambient temperature by $5 \pm 0.1^{\circ} \mathrm{C}$ (2 systems, 'warming-treatment'). In a full-factorial design, systems with ambient and increased temperature were maintained either at ambient $\mathrm{pH}(8.0 \pm$ 0.1 , 'control-treatment') or were acidified to $\mathrm{pH} 7.7 \pm$ 0.1 ('acidification-treatment') through computerregulated (Zac-plus pH controller, $\Delta$ max. $0.1 \mathrm{pH}$ ) $\mathrm{CO}_{2}$ influx upon continuous pH-monitoring (cf. Dickson et al. 2007), using NIST-certified electrodes according to the recommendations of the International Union of Pure and Applied Chemistry (Buck et al. 2002). Because $\mathrm{CO}_{2}$ influx, along with salinity, controls $\mathrm{pH}$, it might have been more appropriate to keep the $\mathrm{CO}_{2}$ influx constant and monitor fluctuations in $\mathrm{pH}$, as this is a better representation of the situation in the field. However, taking into account that $\mathrm{CO}_{2}$ and $\mathrm{pH}$ cannot be studied independently of each other, we were interested in $\mathrm{pH}$ effects per se rather than in hypercapnia (which we studied in a different experiment, see Fehsenfeld et al. 2011), and either approach is considered representative in the study of seawater acidification (Dickson et al. 2007). Owing to the change in temperature over the course of the experiment, the amount of $\mathrm{CO}_{2}$ needed to adjust the $\mathrm{pH}$ to 7.7 varied accordingly. Hence, despite a stable $\mathrm{pH}$, the total alkalinity and the content of inorganic carbon (see below) varied over time by ca. $10 \%$ (see Table 1 ).

The water quality was monitored regularly by measuring the temperature, $\mathrm{pH}$ value (daily) and salinity (once a week). Weekly water samples were collected to monitor parameters of the carbonate system. The total carbon (TC) was measured according to Dickson et al. (2007). The total alkalinity (TA) of the water was calculated using the CO2SYS software (Lewis \& Wallace 1998) and the appropriate parameter and constants (the dissociation constants K1 and K2 according to Mehrbach et al. 1973, refitted by Dickson \& Millero 1987, $\mathrm{KHSO}_{4}$ dissociation constant after Dickson 1990 and the NBS scale [mol kg-1 $\mathrm{H} 2 \mathrm{O}]$ ). About $50 \%$ of the water volume was replaced every week with filtered seawater from the Kiel Fjord.

In total, 40 male shore crabs with a carapace width of 4 to $6 \mathrm{~cm}$, collected at the Kiel Fjord during September 2008, were assigned randomly to one of the systems ( $\mathrm{n}=10$, each). We used both green and red color morphs in about the same proportion to account for potential physiological and behavioral differences (Reid et al. 1997, Styrishave et al. 2004); however, by the end of the experiment, we could not detect any significant difference between the 2 morphs. Hence, the 2 morphs were combined for the analysis of warming and/or acidification effects. The animals were fed twice a week with snail soft bodies and Fucus.

Periwinkles were collected at the Kiel Fjord rocky shore at Bülk Lighthouse, and housed in groups of 100 individuals in the head tank of the 4 water systems. Although this design constrained the status of individual snails as true replicates, we chose this design to ensure that every single snail encountered the presence of potential predators through waterborne cues (cf. Keppel \& Scrosati 2004, Jacobsen \& Stabell 2004) to prevent weakening of the snail shell in response to a predator-free environment (cf. Bibby et al. 2007, Brookes \& Rochette 2007). Along the same line, we aimed to promote the crabs' appetitive behaviour for snail prey by providing water-borne cues of snail presence. Admittedly, we cannot unambiguously distinguish between effects of exposure conditions (warming and acidification) and experimental artifacts of tank effects. However, in the light of studying interaction effects in addition to the individual effects of warming and acidification, we consider this limitation of minor relevance; rather, this design explicitly took into account the joint effects of the snails' response to predator presence (cf. Bibby et al. 2007) and pH on snail performance.

Snails were fed with young Fucus vesiculosus ad libitum. Although Fucus is not their preferred food source (Lubchenco 1983), Littorina littorea does feed on young tissue of the bladder wrack, which is easier to use as food source for laboratory populations than ephemeral green algae (e.g. Ulva) because it lasts longer in the conditions provided by a climate chamber.

\section{Crabs}

As a measure of the break resistance of the cuticle of the chela that each crab (usually right-handed) used for crushing snails after 5 mo of warm and acidified treatment, we determined the force needed to crush the area with denticle-like structures on the insides of the propodus and dactylus, i.e. those structures which essentially participate in cracking molluscan shells, with a texture analyzer (TA.XT2i; pressure sensor $\varnothing 2 \mathrm{~mm}, 3.142 \mathrm{~mm}^{2}$, Stable Micro Systems). For each crab, the same denticle of each claw was measured in the same position. Afterwards, the cuticular thickness in this region was determined optically with a dissection microscope at $10 \times$ magnification and subsequent digital image analysis $( \pm 10 \mu \mathrm{m})$.

For estimating the relative claw strength, snail-fed crabs were stimulated to pinch with their crusher- 
claw into a standardized Plasticine spatula by gently pulling them backwards by their posterior legs. The depths of the imprints of 3 replicate trials per individual were measured, and the deepest imprint was considered a measure of maximal force. Comparison of pre- and post-treatment facilitated estimations of the change in claw strength caused by warming and/or acidification. After the experiment, the closer muscle of the crusher-claw was dissected for biometric measurements (length, width, dry weight).

\section{Periwinkles}

We distinguished between small ( 7 to $8 \mathrm{~mm}$ ) and large (13 to $14 \mathrm{~mm}$ ) individuals. The shell break resistance of individual snails was measured after 5 mo of warm and acidified treatment $(\mathrm{n}=15$ for each size and treatment). The snails were placed flat on the aperture, and to standardize measurements as much as possible, the highest point of the outermost twist was chosen as the contact face for the pressure sensor. Whereas crabs may use different techniques of crushing snail shells (or even twist snail flesh out of the aperture) (Edgell et al. 2008), we considered the shell break resistance of a standardized location on the shell to be a reliable measure of how difficult it would be for a crab to crush a particular snail shell. Snail growth was measured by comparing the live weight, shell width and shell height of 15 individually marked snails (initial size range of 5 to $15 \mathrm{~mm}$ shell width) from each system before and after the treatment.

\section{Predator-prey interactions}

We determined the preferences of crabs for periwinkles of different sizes (small: 7 to $8 \mathrm{~mm}$, medium: 10 to $11 \mathrm{~mm}$, large: 13 to $14 \mathrm{~mm}$ ) before and after the warming-and-acidification treatment. The snails were presented simultaneously in a row, at a distance of $1 \mathrm{~cm}$ from each other. The distance to the crab claws averaged 5 to $6 \mathrm{~cm}$. The chronology of touching and scanning was recorded as well as the observation of which snail was cracked and eaten.

In a no-choice experiment, we determined the handling time, i.e. the time a crab needed from picking up the snail to the start of feeding on the soft body. Handling times were determined within treatments (including control crabs feed- ing on control snails) as well as with control crabs (ambient temperature, ambient $\mathrm{pH}$ ) acting on snails from the warming, acidification and warming-andacidification treatments. The experimental data were standardized by a crab size index (propodal height divided by carapace width) to take into account the size range of experimental crabs.

\section{Statistics}

The statistical analyses of the data were performed using SPSS 18.0. Treatment effects on crab and snail performance were tested using analysis of variance (independent experimental factors: size class [only for snails], experimental warming and experimental acidification). Prior to the ANOVA, the data were tested for normality and variance homogeneity (Bartlett's test) and were arcsin-transformed when necessary. Pairwise Tukey tests were performed for post hoc comparisons $(\alpha=0.05)$.

The preference was analyzed using resampling statistics (www.poptools.org) with 9999 iterations, according to Storry et al. (2006).

\section{RESULTS}

\section{Seawater parameters}

Because both $\mathrm{pH}$ and water temperature were experimentally adjusted, these values varied only slightly over time and deviated only slightly from the set value $( \pm 0.1$ units). The total alkalinity was not influenced by $\mathrm{CO}_{2}$ addition, but inorganic carbon was higher $(p<0.05)$ in the acidified than in the corresponding ambient treatments (Table 1). Salinity was slightly higher in the warm than in the ambient and acidified systems $(p<0.05)$.

Table 1. Average water characteristics over the experimental time span of 5 mo. Data are ranges $(\mathrm{T})$ or median \pm median absolute deviation of weekly measurements (see text); different superscripted letters depict significant $(p<0.05)$ differences among treatments ( $p$-value for TA: 0.11$)$. TA: total alkalinity; DIC: dissolved inorganic carbon; S: salinity

\begin{tabular}{|lccccc|}
\hline & $\begin{array}{c}\mathrm{T} \\
\left({ }^{\circ} \mathrm{C}\right)\end{array}$ & $\mathrm{pH}$ & $\begin{array}{c}\mathrm{TA} \\
\left(\mu \mathrm{mol} \mathrm{kg}{ }^{-1}\right)\end{array}$ & $\begin{array}{c}\mathrm{DIC} \\
\left(\mu \mathrm{mol} \mathrm{kg}{ }^{-1}\right)\end{array}$ & $\mathrm{S}$ \\
\hline Ambient control & $8-18^{\mathrm{a}}$ & $8.0 \pm 0.1^{\mathrm{a}}$ & $1481 \pm 148$ & $1468 \pm 134^{\mathrm{a}}$ & $20 \pm 1^{\mathrm{a}}$ \\
Acidification & $8-18^{\mathrm{a}}$ & $7.7 \pm 0.1^{\mathrm{b}}$ & $1645 \pm 134$ & $1648 \pm 135^{\mathrm{b}}$ & $20 \pm 1^{\mathrm{a}}$ \\
Warming & $13-23^{\mathrm{b}}$ & $8.0 \pm 0.1^{\mathrm{a}}$ & $1462 \pm 129$ & $1418 \pm 114^{\mathrm{a}}$ & $22 \pm 1^{\mathrm{b}}$ \\
$\begin{array}{l}\text { Warming and } \\
\text { acidification }\end{array}$ & $13-23^{\mathrm{b}}$ & $7.7 \pm 0.1^{\mathrm{b}}$ & $1559 \pm 168$ & $1533 \pm 161^{\mathrm{b}}$ & $21 \pm 1^{\mathrm{ab}}$ \\
Significance & $\alpha=0.05$ & $\alpha=0.05$ & $\mathrm{p}=0.11$ & $\alpha=0.05$ & $\alpha=0.05$ \\
\hline
\end{tabular}


Table 2. Carcinus maenas. ANOVA to explain variance in crab claw cuticle thickness, break resistance, length of the closer muscle, muscle mass and strength increment

\begin{tabular}{|lccr|}
\hline & df & $F$ & $p$ \\
\hline Cuticle thickness & & & \\
Model & 3 & 83.671 & $<0.001$ \\
Warming & 1 & 0.297 & 0.594 \\
Acidification & 1 & 1.751 & 0.206 \\
Warming $\times$ Acidification & 1 & 0.001 & 0.980 \\
Break resistance & & & \\
Model & 3 & 65.076 & $<0.001$ \\
Warming & 1 & 0.114 & 0.739 \\
Acidification & 1 & 0.380 & 0.545 \\
Warming $\times$ Acidification & 1 & 0.182 & 0.675 \\
Length of closer muscle & & & \\
Model & 3 & 1.544 .314 & $<0.001$ \\
Warming & 1 & 476.807 & $<0.001$ \\
Acidification & 1 & 270.899 & $<0.001$ \\
Warming $\times$ Acidification & 1 & 440.961 & $<0.001$ \\
Muscle mass & & & \\
Model & 3 & 91.647 & $<0.001$ \\
Warming & 1 & 1.111 & 0.307 \\
Acidification & 1 & 1.032 & 0.324 \\
Warming $\times$ Acidification & 1 & 0.131 & 0.721 \\
Strength increment & & & \\
Model & 3 & 6.345 & 0.002 \\
Warming & 1 & 3.792 & 0.066 \\
Acidification & 1 & 2.051 & 0.168 \\
Warming $\times$ Acidification & 1 & 4.983 & 0.038 \\
\hline
\end{tabular}

\section{Crabs}

The crab survival did not differ among treatments (Mantel-Cox test, $\mathrm{p}=0.95$ ). Similarly, neither the cuticle thickness (2-way ANOVA, Table 2) nor the break resistance of the claw cuticle (2-way ANOVA, Table 2) was affected by any of the treatments.

The length of the claw-closer muscle (Fig. 1) was negatively affected by $\mathrm{pH}$ (2-way ANOVA, Table 2) but not by temperature, whereas the muscle mass was not affected by any treatment (2-way ANOVA, Table 2). Crab claw strength, on average, increased over time in all treatments (Fig. 2). However, the claw strength increment depended on acidification and warming through an interactions of these factors (2-way ANOVA, Table 2), being 4-fold higher in the warming treatments than in the warmingand-acidification treatment, which, in turn, did not differ from the acidification and the control treatment.

\section{Periwinkles}

The shell break resistance depended on the snail size (3-way ANOVA, Table 3) but was mediated by the treatment (Size $\times$ Temperature $\times \mathrm{pH}$ interaction,

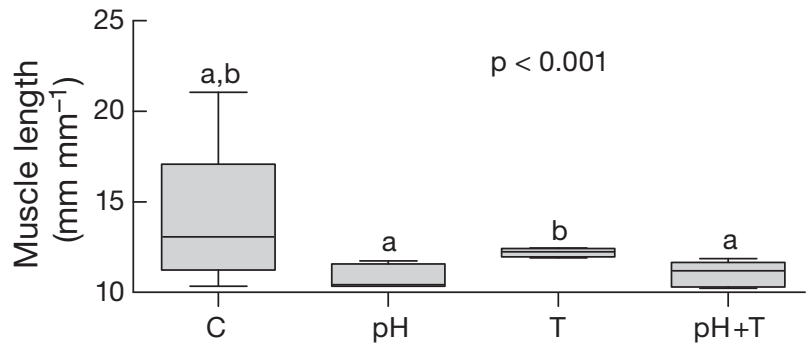

Fig. 1. Carcinus maenas. Length (size-corrected) of the closer-muscle (crushing claw) of acidified $(\mathrm{pH})$, warm $(\mathrm{T})$, or acidified and warm $(\mathrm{pH}+\mathrm{T})$ treated versus untreated $(\mathrm{C})$ crabs. Box plots represent minimum, lower quartile, median, upper quartile and maximum values $(n=10)$; the $\mathrm{p}$-value depicts the overall significance of the ANOVA model; different lower-case letters indicate significant differences $(\alpha=$ 0.05) according to pairwise posthoc Tukey tests

Table 3). Small snails ( 7 to $8 \mathrm{~mm}$ ) were more difficult to break after the warming-and-acidification treatment than after the acidification treatment (Fig. 3), whereas large snails remained entirely unaffected.

\section{Predator-prey interactions}

Both before and after the 5 mo treatment, crabs from all of the treatments preferred large snails significantly over medium-sized or small snails ( $p<0.05$; not shown), even though the crabs were often unable to crush the snails open. We did not observe any significant difference in prey choice for small or medium-sized snails $(p>0.3)$.

Control crabs needed less time to successfully handle large snails from the acidification $(p=0.05)$ or warming-and-acidification treatments $(p=0.09)$ than large control snails (Fig. 4). Hence, for control crabs, the temperature treatment of snails significantly

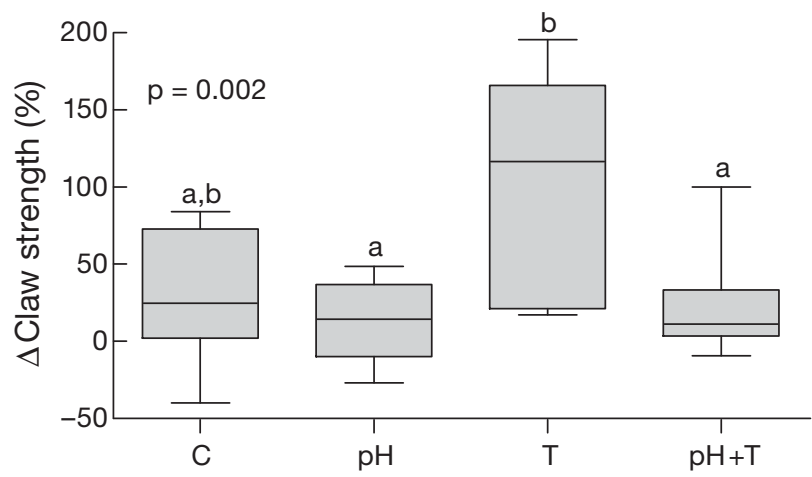

Fig. 2. Carcinus maenas. Change in claw strength of crabs during 5 mo of acidified $(\mathrm{pH})$, warm $(\mathrm{T})$, or acidified and warm $(\mathrm{pH}+\mathrm{T})$ treatment versus control crabs (C). See Fig. 1 for complete description of symbols 
Table 3. Littorina littorea. ANOVA to explain variance in snail shell break resistance

\begin{tabular}{|lccc|}
\hline & df & $F$ & $\mathrm{p}$ \\
\hline Model & 7 & 300.827 & $<0.001$ \\
Size & 1 & 4.464 & 0.036 \\
Warming & 1 & 0.545 & 0.461 \\
Acidification & 1 & 0.124 & 0.725 \\
Size $\times$ Warming & 1 & 0.121 & 0.728 \\
Size $\times$ Acidification & 1 & 0.865 & 0.354 \\
Warming $\times$ Acidification & 1 & 3.021 & 0.084 \\
Size $\times$ Warming $\times$ Acidification & 1 & 5.631 & 0.019 \\
\hline
\end{tabular}

affected the prey-handling time (3-way ANOVA, Table 4), but $\mathrm{pH}$ effects tended to be size-dependent (Size $\times \mathrm{pH}$ interaction, Table 4). Overall, crabs from all treatments were able to successfully prey upon both control snails (data not shown) and snails from their own treatment in about the same time (Fig. 5), and only snail size affected handling time (Table 4 ).

\section{DISCUSSION}

\section{General findings}

According to our findings, both warming and acidification affect the individual performance of both crabs and their potential prey with respect to predation-sensitive characteristics. However, the effects of warming and/or acidification were not independent but interacted with each other. The claw-strength increment in crabs was promoted by warming (as compared to ambient conditions in the control), but this trend was counteracted by simultaneous acidification, and the claw-strength increment under acidification

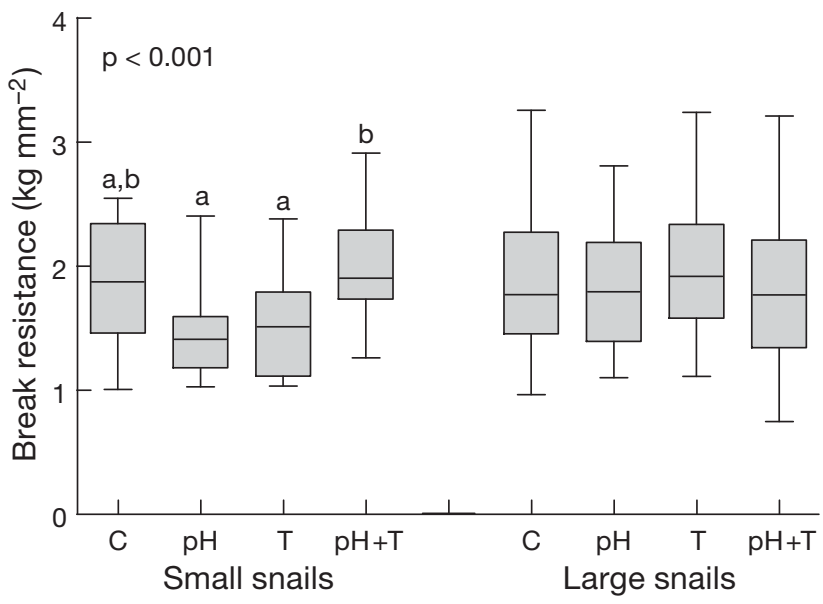

Fig. 3. Littorina littorea. Shell break resistance of acidified $(\mathrm{pH})$, warm $(\mathrm{T})$, or acidified and warm $(\mathrm{pH}+\mathrm{T})$ treated versus untreated (C) snails. See Fig. 1 for further details

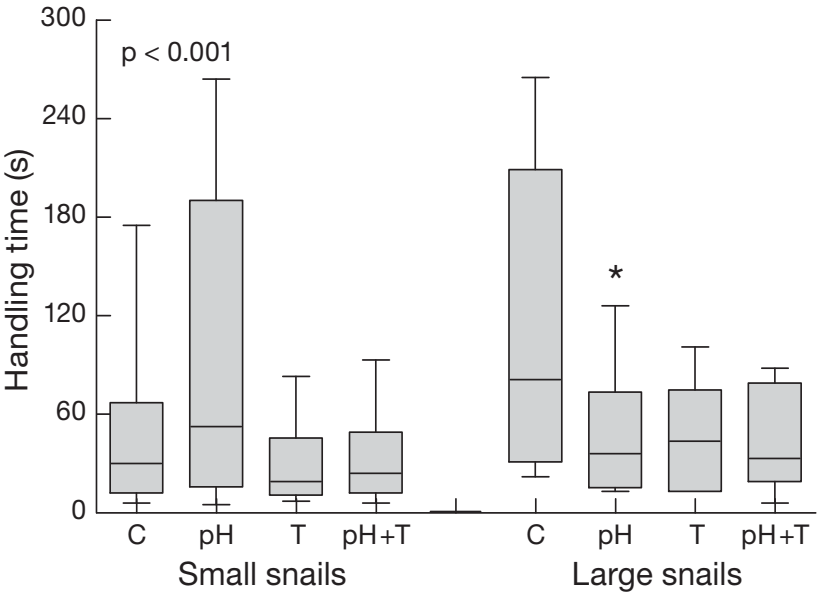

Fig. 4. Handling time of acidified ( $\mathrm{pH})$, warm $(\mathrm{T})$, or acidified and warm $(\mathrm{pH}+\mathrm{T})$ treated snails Littorina littorea by crabs Carcinus maenas maintained under control conditions. Box plots: minimum, lower quartile, median, upper quartile and maximum values $(n=10)$; $p$-value: overall significance of the ANOVA model; asterisk: significant difference between treatment and control data within snail size class according

to pairwise post hoc Tukey tests $\left({ }^{*} p<0.05\right)$. C: control

did not differ from that in the control. The shell strength of small snails was negatively affected by either warm or acidified conditions, but simultaneous warming and acidification increased the shell strength. Hence, the predicted concomitant changes in temperature and $\mathrm{pH}$ may have contrasting effects on calcifying invertebrates, as has been shown for the effects of warming and desalination on Mytilus edulis (Kossak 2006). Surprisingly, it was large snails that

Table 4. ANOVA results to explain variance in handling time for treatment snails by control crabs (Control) and treatment snails by crabs from the same treatment (Treatment)

\begin{tabular}{|lccc|}
\hline & df & $F$ & $p$ \\
\hline Control & & & \\
Model & 7 & 9.151 & $<0.001$ \\
Size & 1 & 0.624 & 0.433 \\
Warming & 1 & 5.911 & 0.018 \\
Acidification & 1 & 0.066 & 0.798 \\
Size $\times$ Warming & 1 & 0.041 & 0.842 \\
Size $\times$ Acidification & 1 & 3.696 & 0.059 \\
Warming $\times$ Acidification & 1 & 0.052 & 0.821 \\
Size $\times$ Warming $\times$ Acidification & 1 & 3.014 & 0.088 \\
Treatment & & & \\
Model & 7 & 3.736 & 0.003 \\
Size & 1 & 6.472 & 0.016 \\
Warming & 1 & 0.257 & 0.616 \\
Acidification & 1 & 0.436 & 0.514 \\
Size $\times$ Warming & 1 & 0.018 & 0.895 \\
Size $\times$ Acidification & 1 & 0.884 & 0.354 \\
Warming $\times$ Acidification & 1 & 2.017 & 0.165 \\
Size $\times$ Warming $\times$ Acidification & 1 & 0.534 & 0.470 \\
\hline
\end{tabular}




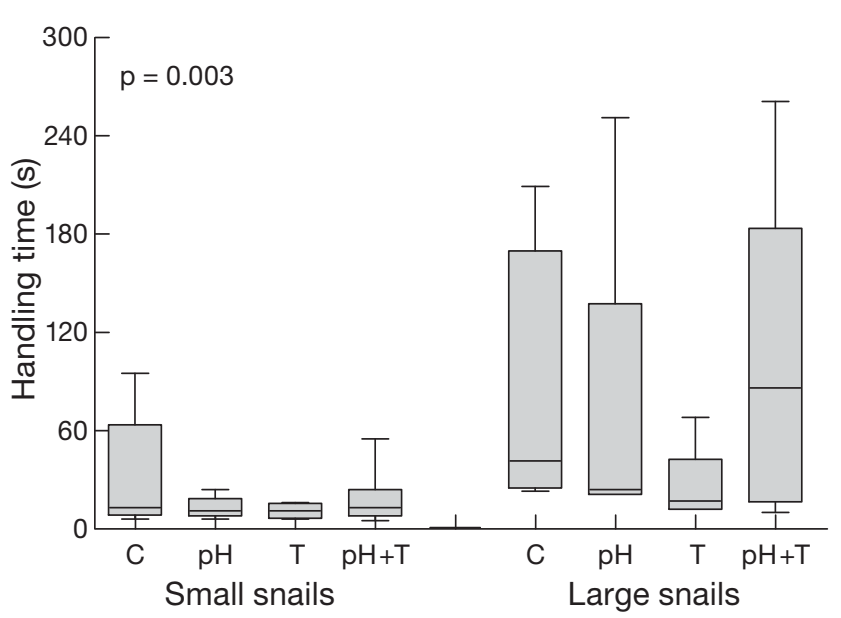

Fig. 5. Handling time of treated ( $\mathrm{pH}$ : acidified; $\mathrm{T}$ : warm; ph $+\mathrm{T}$ : acidified and warm) or untreated (C) snails Littorina littorea by accordingly treated crabs Carcinus maenas. Box plots: minimum, lower quartile, median, upper quartile and maximum values $(n=10)$; $p$-value: overall significance of the ANOVA model. According to pairwise posthoc Tukey tests, no significant differences between treatment and control data exist within snail size classes

had been exposed to warming and/or acidification for $5 \mathrm{mo}$, and not small snails, that were easier to prey upon by crabs kept under ambient control conditions. Although we cannot provide any sound explanation for this counter-intuitive finding, this underlines the fact that it is not sufficient to study species-specific effects of environmental change to deduce effects on interactions because the latter depend on multiple external and intrinsic factors that may be overlooked from data at the single-species level.

Admittedly, we cannot unambiguously distinguish between effects of exposure conditions (warming and acidification) and experimental artifacts of tank effects because the individuals of the same treatment were maintained within the very same water circulation system. Through our design, however, we ensured that both predators and prey were aware of the presence of their counterpart, inducing both predator appetitive behaviour for this particular prey and antipredator shell strengthening (cf. Bibby et al. 2007, Brookes \& Rochette 2007).

At the community scale of predator-prey interactions, the relationship between crab predators and snail prey was not affected by warming or acidification: regardless of treatment, crabs always took the same time to successfully prey upon snails, and handling time was solely dependent on snail size. Along the same line, crabs always preferred larger snails over smaller ones, when given a choice, even though they often were not able to crack the large ones. We discuss these issues in turn.

\section{Effects on crabs}

Although acidification through $\mathrm{CO}_{2}$ influx results in increased $\mathrm{Ca}^{2+}$ solubility and decreased carbonate availability for calcification processes, the crabs' cuticle was obviously not affected by the experimental manipulation. However, only 3 out of 40 crabs molted during our 5 mo experiment that mimicked winter and early spring conditions in the western Baltic Sea. Because the incorporation of calcium carbonate into the exoskeleton entirely takes place during a short phase just after ecdysis (Adelung 1971), we might have observed decreasing cuticle strength had we achieved more molting events.

The claw strength of crabs, however, depends on the potential to mechanically shorten the closer muscle (Caiozzo \& Baldwin 1997), rather than on cuticle characteristics. Thus, the longer a muscle, the greater its theoretical force potential (Josephson \& Stokes 1989, Josephson 1999). Crabs under acidified conditions (both ambient and warm) had shorter muscles than crabs under control or warming conditions. Furthermore, the claw strength increment was less pronounced under acidified conditions than under ambient and warm conditions. Although Carcinus maenas exhibits only weak overall response to hypercapnia (Fehsenfeld et al. 2011), and other crab species, such as Cancer magister (Pane \& Barry 2007) and Necora puber (Spicer et al. 2007), are known to compensate for short-term extracellular acidification of body fluids, such homeostasis poses a metabolic cost (shown for Necora puber, Small et al. 2010). Brittle stars exhibit muscle wastage upon seawater acidification, due to increased metabolism and calcification (Wood et al. 2008). Furthermore, $\mathrm{CO}_{2}$-induced stress weakens crabs' resilience to additional environmental stressors. Metzger et al. (2007) found enhanced sensitivity to heat upon short-term hypercapnia in Cancer pagurus, and the thermal window (temperature range of optimal performance) of Hyas araneus narrows under moderate increases in $\mathrm{CO}_{2}$ levels (Walther et al. 2009). In Callinectes sapidus, seawater acidification compromises anti-pathogen defense through reduced tissue oxygen and $\mathrm{pH}$ (Tanner et al. 2006). We conclude that counteracting acidification and/or warming is likely to have caused muscle wastage in C. maenas in our study.

\section{Effects on snails}

Many calcifying mollusks exhibit reduced calcification and growth rates under experimental acid- 
ification (reviewed by Doney et al. 2009). In the present study, however, large snails were not affected by warming or acidification in terms of shell strength, and small snails that had been treated in warm and acidified water did not differ from control snails. However, small snails under acidified conditions had significantly weaker shells than small snails under warm and acidified conditions. In accordance with our findings in a system in which prey organisms were confronted with predator presence, predator-induced shell thickening in Littorina littorea was disrupted by acidification (Bibby et al. 2007). Ellis et al. (2009) found effects of acidification on Littorina obtusata mostly in embryonic and hatching individuals in that hatchlings exhibited altered shell morphology. Similarly, Gazeau et al. (2010) observed reduced growth rates of planktonic Mytilus edulis larvae, and the shells of young mussels were thinner upon experimental acidification than in control groups. Hence, acidification seems to affect mollusks mostly during early stages of their lives, whereas later stages are less affected. Smaller mollusks are more prone to predation by e.g. crabs (cf. Enderlein et al. 2003), and shell strength mediates the predator-prey interactions of mollusks (cf. Bibby et al. 2007). In the present study, the handling time significantly depended on snail size. However, crabs, when given a choice, preferred large snails over small snails, although they may not always be able to crack the shells of the latter. Potential consequences on the community level will be discussed below.

As is the case with crabs, adult mollusks may possess strong physiological mechanisms to counteract the impacts of acidified seawater on general performance. However, these mechanisms come at an energetic cost, which can result in reduced growth during long-term exposures (cf. Beesley et al. 2008 for Mytilus edulis). In our present study, warming seemed to neutralize the negative effect of acidification on small snails, as has similarly been shown by Kossak (2006) for interacting effects of temperature and salinity on $M$. edulis. Snails from the warm and acidified treatment were better able to build up their shells (in response to the presence of a predator, cf. Bibby et al. 2007) than were snails in acidified treatments at ambient temperature. Warming did not significantly affect the total alkalinity or dissolved inorganic carbon in seawater as compared to the corresponding ambient treatments, whereas acidification did (Table 1). In contrast, warming increased salinity, but this effect was counteracted by simultaneous acidification (Table 1). The major pressure of ocean acidification on calcifying organisms will be continual dissolution of the $\mathrm{CaCO}_{3}$ structures rather than carbonate concentration (e.g. Büdenbender et al. 2001, Rodolfo-Metalpa et al. 2011); however, we did not determine the saturation states of seawater in our treatments, so we cannot provide any explanation for the mitigation of negative acidification effects by simultaneous warming. Interestingly, Diaz-Pulido et al. (2011) observed the opposite effect of warming in that warming amplified the negative effects of high $p \mathrm{CO}_{2}$ on crustose coralline algae.

\section{Effects on crab-snail interactions}

Reduced shell strength of calcifying prey organisms may have consequences for both individual survival and population growth. Similarly, the ability of predators to prey upon shelled prey determines not only individual growth and survival but also the fate of local populations. Littorina littorea produces thicker shells in the presence of predators, but this response is disrupted at low seawater $\mathrm{pH}$ (Bibby et al. 2007). However, snails apparently compensate for a lack of morphological defense by increasing their avoidance behavior (cf. Rochette \& Dill 2000), which, in turn, could affect their interactions with other organisms. However, broader implications of seawater acidification for ocean ecosystems are still not well known (Doney et al. 2009).

Irrespective of any effects of acidification and/or warming on snails or crabs, there were only marginal differences in the handling time of small snails by crabs that had been treated under ambient control conditions, and crabs from acidified and/or warm conditions needed the same time to handle small snails from any treatment condition. By contrast, large snails from both acidified and acidified and warm conditions were faster to handle by crabs from control conditions than were large snails from control conditions. Taking into account only the interactions of crabs and snails that had been treated the same way, it is obvious that neither warming nor acidification affected the ability of crabs to prey upon snails nor was the predators' choice for prey size altered.

How our findings translate into changes in community structure under environmental change remains to be studied. When interpreting the present findings, 2 aspects should be considered.

(1) Species may adapt to changes in environmental conditions, but the recent rate of environmental change is higher than ever before, and it is this rate, possibly hampering adaptation, that is of interest to ecologists (IPCC 2007, Tripati et al. 2009). Experiments on the effects of climate change on organisms 
tend to impose an even faster transition from ambient to (projected) future conditions. Furthermore, most studies only analyze a single generation, thus missing any adaptations that occur across generations. Whether and to what degree species will be able to adapt to the changing environmental conditions is difficult-if not impossible-to deduce from such experiments, and will only become apparent from the composition of future communities.

(2) Indirect effects of predators on potential prey organisms may be as strong as direct effects, and prey may be 'scared to death' (i.e. respond in an extreme and ultimately detrimental way) by the presence of predators (Preisser et al. 2005). For example, Bibby et al. (2007) presented evidence that Littorina littorea exhibit changed behavior in response to Carcinus maenas when seawater acidification hampered the otherwise induced strengthening of the snails' shell. Such an increased avoidance behavior, possibly size-dependent, may have profound effects on the ecological interactions of individuals, potentially impairing feeding, growth and reproduction. Preferences for prey that is difficult to handle (here, large snails) over easy-to-handle prey (here, small snails with short handling time) obscure predictions at the community level. Because we did not include behavioral studies on snails in our analysis of interactions, we cannot entirely exclude that, beyond our findings, environmental change will translate into changes both in (indirect) predator-prey interactions and at the community level.

\section{CONCLUSIONS}

Despite our experimental design without separate treatment of predators and prey, our present findings suggest that both crabs and snails are affected by warming and/or acidification in the presence of their prey and their predators, respectively. Nevertheless, there may be little change in predator-prey interactions at the community level. If both crab claw force and snail shell strength decrease upon acidification, prey size choice by crabs (cf. Enderlein et al. 2003 for Mytilus edulis) will probably not be affected. Therefore, marine communities that are based on calcifying invertebrates may be less affected by warming and acidification than would be expected from species-specific responses to environmental change.

Whether our findings mean that interactions between calcifying predators and their calcifying prey will remain unaffected by the predicted changes in seawater temperature and $\mathrm{pH}$ at the community level warrants further detailed studies. Such future studies will have to take direct and indirect interspecific interactions into account as well as the simultaneous action of multiple environmental changes, such as the concomitant increase in temperature and decrease in $\mathrm{pH}$, which may mitigate each other (Tables $2 \& 4$, Fig. 2; but see also Diaz-Pulido et al. 2011).

Acknowledgements. The analyses of water chemistry were performed by S. Malien (IFM-GEOMAR, FB3: Marine Ecology). M. Wahl, IFM-GEOMAR, provided access to the texture analyzer.

\section{LITERATURE CITED}

Adelung D (1971) Untersuchungen zur Häutungsphysiologie der dekapoden Krebse am Beispiel der Strandkrabbe Carcinus maenas. Helgoländer Wiss Meeresunters 22:66-119

Beesley A, Lowe DM, Pascoe CK, Widdicombe S (2008) Effects of $\mathrm{CO}_{2}$-induced seawater acidification on the health of Mytilus edulis. Clim Res 37:215-225

Bibby R, Cleall-Harding P, Rundle S, Widdicombe S, Spicer J (2007) Ocean acidification disrupts induced defences in the intertidal gastropod Littorina littorea. Biol Lett 3: 699-701

Brookes JI, Rochette R (2007) Predator-induced shell thickening in the intertidal gastropod Littorina obtusata: developmental by-product or active physiological response? J Evol Biol 20:1015-1027

Buck RP, Rondinini S, Covington AK, Baucke FGK and others (2002) Measurement of pH. Definition, standards and procedures (IUPAC Recommendations 2002). Pure Appl Chem 74:2169-2200

Büdenbender J, Riebesell U, Form A (2011) Calcification of the Arctic coralline red algae Lithothamnion glaciale in response to elevated $\mathrm{CO}_{2}$. Mar Ecol Prog Ser 441:79-87

> Caiozzo VJ, Baldwin KM (1997) Determinants of work produced by skeletal muscles: potential limitations of activation and relaxation. Am J Physiol 273:C1049-C1056

Caldeira K, Wickett ME (2003) Anthropogenic carbon and ocean $\mathrm{pH}$. Nature 425:365

Diaz-Pulido G, Anthony KRN, Kline DI, Dove S, Hoegh-Guldberg $O$ (2012) Interactions between ocean acidification and warming on the mortality and dissolution of coralline algae. J Phycol 48:32-39

$>$ Dickson AG (1990) Standard potential of the reaction $\mathrm{AgCl}_{\mathrm{s}}+1 / 2 \mathrm{H}_{2 \mathrm{~g}}=\mathrm{Ag}_{\mathrm{s}}+\mathrm{HCl}_{\mathrm{aq}}$ and the standard acidity constant of the ion $\mathrm{HSO}_{4}{ }^{-}$in synthetic sea water from $273.15 \mathrm{~K}$ to $318.15 \mathrm{~K}$. J Chem Thermodyn 22:113-127

> Dickson AG, Millero FJ (1987) A comparison of the equilibrium-constants for the dissociation of carbonic-acid in seawater media. Deep-Sea Res 34:1733-1743

Dickson AG, Sabine CL, Christian JR (2007) Guide to best practices for ocean $\mathrm{CO}_{2}$ measurements. PICES Special Publication 3, Sidney, BC

> Doney SC, Fabry VJ, Feely RA, Kleypas JA (2009) Ocean acidification: the other $\mathrm{CO}_{2}$ problem. Annu Rev Mar Sci 1:169-192

> Edgell TC, Brazeau C, Grahame JW, Rochette R (2008) Simultaneous defense against shell entry and shell crushing in a snail faced with the predatory shorecrab Carcinus maenas. Mar Ecol Prog Ser 371:191-198

Ellis RP, Bersey J, Rundle SD, Hall-Spencer JM, Spicer JI 
(2009) Subtle but significant effects of $\mathrm{CO}_{2}$ acidified seawater on embryos of the intertidal snail, Littorina obtusata. Aquat Biol 5:41-48

Enderlein P, Moorthi S, Röhrscheid H, Wahl M (2003) Optimal foraging versus shared doom effects: interactive influence of mussel size and epibiosis on predator preference. J Exp Mar Biol Ecol 292:231-242

Fehsenfeld S, Kiko R, Appelhans Y, Towle DW, Zimmer M, Melzner F (2011) Effects of elevated seawater $\mathrm{pCO}_{2}$ on gene expression patterns in the gills of the green crab, Carcinus maenas. BMC Genomics 12:488

Gazeau F, Gattuso JP, Dawber C, Pronker AE, Peene F, Peene $\mathrm{J}$ (2010) Effect of ocean acidification on the early life stages of the blue mussel (Mytilus edulis). Biogeosciences Discuss 7:2927-2947

> Hall-Spencer JM, Rodolfo-Metalpa R, Martin S, Ransome E and others (2008) Volcanic carbon dioxide vents show ecosystem effects of ocean acidification. Nature 454:96-99

HELCOM (The Helsinki Commission) (2007) Climate change in the Baltic Sea area. Balt Sea Environ Proc 111, Baltic Marine Environment Protection Commission, Helsinki

IPCC (2007) Climate change 2007: the physical science basis. Contribution of Working Group I to the Fourth Assessment Report of the Intergovernmental Panel on Climate Change. Cambridge University Press, Cambridge

> Jacobsen HP, Stabell OB (2004) Antipredator behaviour mediated by chemical cues: the role of conspecific alarm signalling and predator labelling in the avoidance response of a marine gastropod. Oikos 104:43-50

Johnson LJ (1999) Size assortative mating in the marine snail Littorina neglecta. J Mar Biol Ass UK 79:1131-1132

> Josephson RK (1999) Dissecting muscle power output. J Exp Biol 202:3369-3375

Josephson RK, Stokes DR (1989) Strain, muscle length and work output in a crab muscle. J Exp Biol 145:45-61

Keppel E, Scrosati R (2004) Chemically mediated avoidance of Hemigrapsus nudus (Crustacea) by Littorina scutulata (Gastropoda): effects of species coexistence and variable cues. Anim Behav 68:915-920

Kossak U (2006) How climate change translates into ecological change: impacts of warming and desalination on prey properties and predator-prey interactions in the Baltic Sea. PhD dissertation, Christian-Albrechts-Universität zu Kiel

Lewis E, Wallace DWR (1998) Program developed for $\mathrm{CO}_{2}$ system calculations. ORNL/CDIAC-105. Carbon Dioxide Information Analysis Center, Oak Ridge National Laboratory, U.S. Department of Energy, Oak Ridge, Tennessee

Lubchenco J (1983) Littorina and Fucus: effects of herbivores, substratum heterogeneity, and plant escapes during succession. Ecology 64:1116-1123

Mehrbach C, Culberson CH, Hawley JE, Pytkowicz RM (1973) Measurement of the apparent dissociation constants of carbonic acids in seawater at atmospheric pressure. Limnol Oceanogr 18:897-907

Metzger R, Sartoris FJ, Langebuch M, Pörtner HO (2007) Influence of elevated $\mathrm{CO}_{2}$ concentrations on thermal tolerance of the edible crab, Cancer pagurus. J Therm Biol 32: $144-151$

Ohde S, Hossain MMM (2004) Effects of $\mathrm{CaCO}_{3}$ (aragonite) saturation state of seawater on calcification of Porites coral. Geochem J 38:613-621

Pane EF, Barry JP (2007) Extracellular acid-base regulation during short-term hypercapnia is effective in a shallowwater crab, but ineffective in a deep-sea crab. Mar Ecol Prog Ser 334:1-9
Preisser EL, Bolnick DI, Bernard MF (2005) Scared to death? The effects of intimidation and consumption in predatorprey interactions. Ecology 86:501-509

Reid DG, Abelló P, Kaiser MJ, Warman CG (1997) Carapace colour, inter-moult duration and the behavioural and physiological ecology of the shore crab Carcinus maenas. Estuar Coast Shelf Sci 44:203-211

Roberts DJ, Hughes RN (1980) Growth and reproductive rates of Littorina rudis from 3 contrasted shores in North Wales, UK. Mar Biol 58:47-54

Rochette R, Dill ML (2000) Mortality, behavior and the effects of predators on the intertidal distribution of littorinid gastropods. J Exp Mar Biol Ecol 253:165-191

Rodolfo-Metalpa R, Houlbrèque F, Tambutté É, Boisson F and others (2011) Coral and mollusc resistance to ocean acidification adversely affected by warming. Nature Clim Change 1:308-312

> Ross B, Berry AJ (1991) Annual and lunar reproductive cycles in Littorina saxatilis (Olivi) and differences between breeding in the marine Firth of Forth and the Forth estuary. J Molluscan Stud 57:347-358

Siegel H, Gerth M, Tschersich G (2006) Sea surface temperature development of the Baltic Sea in the period 19902004. Oceanologia 48:119-131

> Small D, Calosi P, White D, Spicer JI, Widdicombe S (2010) Impact of medium-term exposure to $\mathrm{CO}_{2}$ enriched seawater on the physiological functions of the velvet swimming crab Necora puber. Aquat Biol 10:11-21

SMHI (2008) On effects and monitoring of marine acidification in the seas surrounding Sweden. Andersson $\mathrm{P}$ (ed) Oceanografiska Enheten Oceanography Report 92, Gothenburg, Sweden

- Sommer U (2001) Reversal of density dependence of juvenile Littorina littorea (Gastropoda) growth in response to periphyton nutrient status. J Sea Res 45:95-103

Spicer JI, Raffo A, Widdicombe S (2007) Influence of $\mathrm{CO}_{2}$ related seawater acidification on extracellular acid-base balance in the velvet swimming crab Necora puber. Mar Biol 151:1117-1125

Storry KA, Weldrick CK, Mews M, Zimmer M, Jelinski DE (2006) Intertidal coarse woody debris: a spatial subsidy as shelter or feeding habitat for gastropods? Estuar Coast Shelf Sci 66:197-203

Styrishave B, Rewitz K, Andersen O (2004) Frequency of moulting by shore crabs Carcinus maenas (L.) changes their colour and their success in mating and physiological performance. J Exp Mar Biol Ecol 313:317-336

Tanner CA, Burnett LE, Burnett KG (2006) The effects of hypoxia and $\mathrm{pH}$ on phenoloxidase activity in the Atlantic blue crab, Callinectes sapidus. Comp Biochem Physiol A 144:218-223

The Royal Society (2005) Ocean acidification due to increasing atmospheric carbon dioxide. The Royal Society, London, available at http://royalsociety.org

Tripati AK, Roberts CD, Eagle RA (2009) Coupling of $\mathrm{CO}_{2}$ and ice sheet stability over major climate transitions of the last 20 million years. Science 326:1394-1397

> Trussell CG, Ewanchuk PJ, Bertness MD (2002) Field evidence of trait-mediated indirect interactions in a rocky intertidal food web. Ecol Lett 5:241-245

> Walther K, Sartoris FJ, Bock C, Pörtner HO (2009) Impact of anthropogenic ocean acidification on thermal tolerance of the spider crab Hyas araneus. Biogeosciences 6:2207-2215

Wood HL, Spicer JI, Widdicombe S (2008) Ocean acidification may increase calcification rates, but at a cost. Proc Biol Sci 275:1767-1773

Submitted: October 19, 2010; Accepted: February 13, 2012

Proofs received from author(s): March 14, 2012 